\title{
Regional inequalities in front-office services \\ Focus shift in e-government front offices and their regional projections in Hungary
}

Balázs Benjámin Budai In developed countries, administrative front

National University of Public

Service, Hungary

E-mail: budai.balazs@uni-nke.hu

István Tózsa

National University of Public

Service, Hungary

E-mail: istvan.tozsa@uni-nke.hu

Keywords:

e-administration facilities, regional inequalities

of front-office services,

Web 2.0 and social media impact

on e-government,

administratively disadvantaged

municipalities offices are becoming increasingly more sophisticated, with e-government facilities and applications. Public administrations are finding ever-improving interfaces to serve customers while optimising their operations. They are also discovering the increasing functionality that can be achieved through popular social media platforms. At the same time Hungary is responding to these phenomena with a significant phase delay, and regional inequality has been observed. Although public administration should show a uniform level of development and service portfolio in each part of the country, Hungary is experiencing very large extremes, which do not always stem from the existing framework, disadvantages, settlement size, and ethnic backgrounds. A great deal is at stake if uniform development is not ensured: some areas will become invisible not only in cyberspace and in Hungary's thematic maps, but at the same time will not be able to provide basic administrative services to those who live there. These areas are currently referred to as 'administratively disadvantaged' districts. This situation worsens the livelihood of the affected population and on the longterm the survival chances of these settlements as well. In this paper, we shed some light on the factors responsible for the regional inequalities in the infocommunication technologies (ICT) facilities of Hungarian local governments. Similar trends have been observed in Slovenia, Slovakia, and the Czech Republic, too. 


\section{Introduction}

The patterns in education, standard of living, taxation capacity, health status and life expectancy determine the territorial differences in e-government services. The government's centralisation efforts precisely aim to eliminate these territorial disparities. The focus of this study, organised by the Municipal Coordination Office of the Ministry of the Interior is the e-government front office, and particularly, the analysis of office websites and community spaces. We assume that in areas where the economic performance and potential of the settlements are lower, e-government interfaces are also in a more rudimentary state. In the course of our analysis, we would like to indicate that the existence of an IT strategy, the condition of computers, the status of websites, the use of social media, and the management and patterns of announcements exhibit a correlation with the position and development of a settlement. We also attempt to detect and map the geographical distribution of the development of municipal informatics. Similar studies have been conducted in other Central- and Eastern European countries (CEE countries), concluding that the development of ICT-based smart cities is decelerating due to human factors related to informatics (Klimovský et al. 2016). The administrative services provided in the front office as well as in health care should, in principle, exhibit the same standard throughout the country. With regard to modernisation, data on the presence or absence of information-communication and computer tools is measurable and may be used to indicate the regional differences in the level of development of administrative modernisation.

\section{Methodology}

When establishing our methodology for surveying the ICT facilities of Hungarian local municipalities, we considered the methods used abroad, too. Hungary's neighbour in the Central European region that could serve as an example to follow in the field of e-government is Slovenia, which ranks higher than Hungary in the EGovernment Readiness Index list, and has the best rankings in this respect together with Estonia among former socialist countries. Pinterič (2010) describes a method used in a Slovenian survey on citizens regarding e-communications by public administrations. It is based on sending e-mails with relevant questions to the general e-mail addresses of the most important public administration and government institutions. Based on the results it could be argued that even in Slovenia considerable progress has been made in providing quality public services in terms of the quality of correspondence with citizens. Slovenian municipalities usually have the necessary human and technical resources but their employees have to be additionally educated in 'electronic literacy' as well as in understanding that public administration has to be changed from a self-sufficient organisation to public service, enabling people to deal with things beyond bureaucratic matters.

Regional Statistics, Vol. 10. No. 2. 2020: 206-227; DOI: 10.15196/RS100212 
Thus, we decided to use a similar method, based on an extended online questionnaire accompanied by personal interviews. The online questionnaire survey was conducted between 17 February and 3 March 2017. The questionnaire consisted of 34 questions, which asked about the information management and capabilities of the local governments of the settlements. The questionnaire was received by all Hungarian municipalities (through the Integriertes Lern-, Informations- und Arbeitskooperations-System [German for "Integrated Learning, Information and Work Cooperation System" - ILIAS] system of the Ministry of the Interior), and it was completed and returned by almost four-fifth of settlements. This response rate constitutes a remarkably high value in the category of online surveys. ${ }^{1}$ A total of 4,100 respondents from 2,520 out of a total of 3,200 municipalities participated in the survey; usually a clerk or the mayor answered the questions. (At least one response was received from nearly 2,700 settlements. When processing the data, we also took into account questionnaires with partial responses, which were technically not fully complete; thus we obtained data from 2,645 settlements.) SPSS 22 and MapInfo 12, a GIS mapping application were used to process the data. The sample size we selected can be considered representative in the following three respects based on the fit test:

\footnotetext{
${ }^{1}$ A first version of the questionnaire was tested in 40 settlements between 16 and 24 January 2017, in the framework of personal interviews involving 40 main research organisers. The results of the testing were presented by the research organisers on 27.01.2017, within the framework of the Research Support Workshop. The meeting was attended by research leaders, colleagues performing operational tasks, and methodological and system design experts, namely Gábor Csanádi and Miklós Illéssy. The results of the questionnaire testing were recorded, the experts compiled their professional suggestions, and the research leaders finalised their questions. The final remaining questionnaire issues were prioritised by the two methodological and systems design experts.
}

Regional Statistics, Vol. 10. No. 2. 2020: 206-227; DOI: 10.15196/RS100212 


\section{Respondents of the online questionnaires by Hungarian counties}

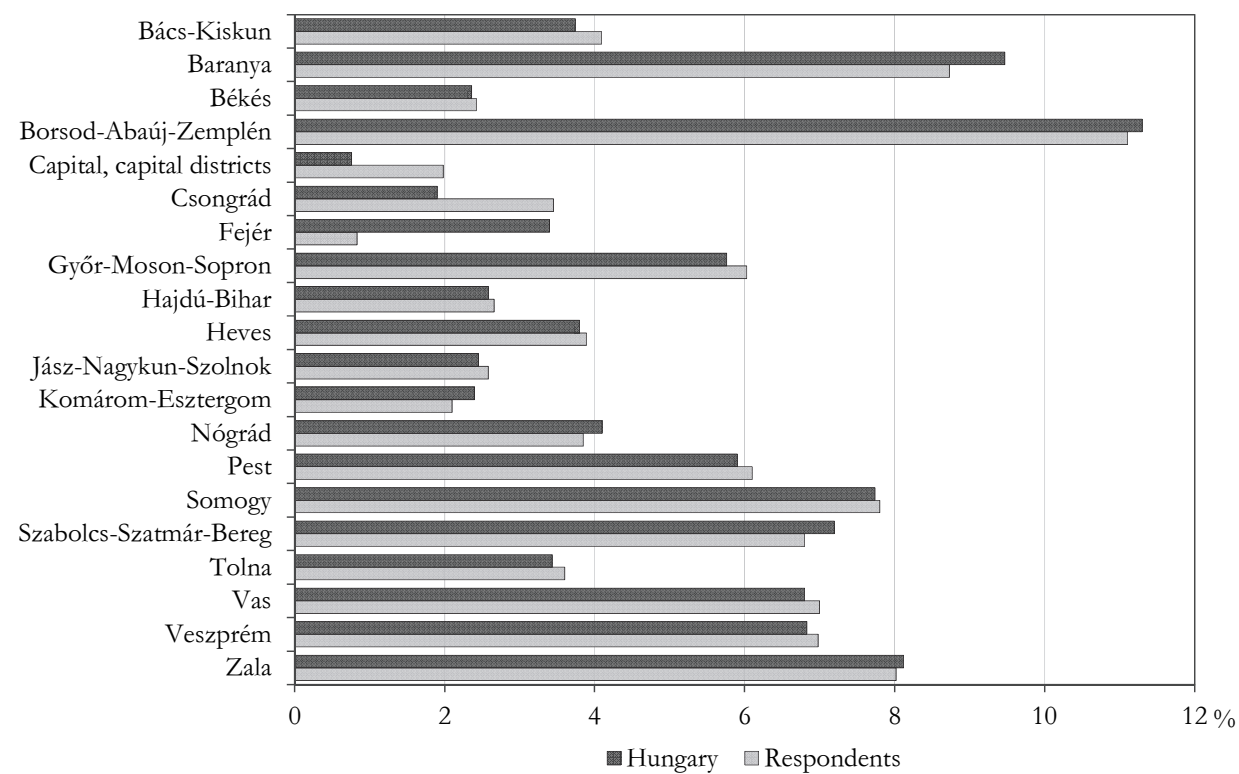

Source: Ministry of the Interior, Önkormányzati Fejlesztések figyelemmel Kísérése II. (Hungarian for Monitoring of Development Projects of Local Governments II. - ÖFFK II.).

Based on the fit test, the responses can be considered representative (Chi-square $=5.74, \mathrm{df}=19, \mathrm{p}=0.999$ ) because the municipalities' answers were of the same distribution as the national average.

Figure 2

\section{Respondents to the online survey based on the population of the settlements}

Number of settlements, $\%$

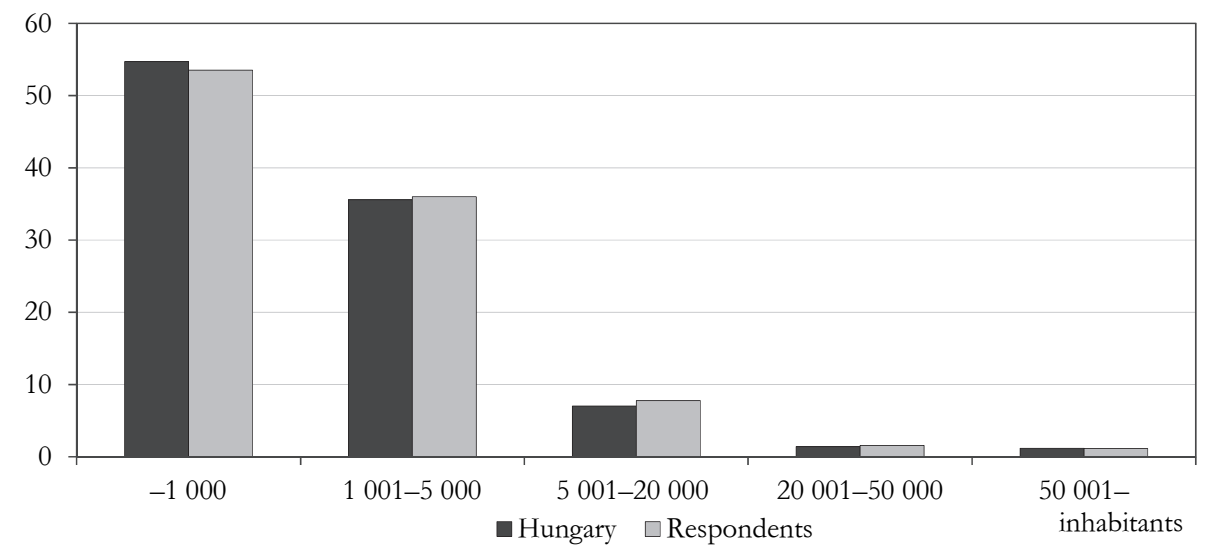

Source: Ministry of the Interior, ÖFFK II.

Regional Statistics, Vol. 10. No. 2. 2020: 206-227; DOI: 10.15196/RS100212 
Based on the fit test, the survey can be considered representative (Chisquare $=3.00, \mathrm{df}=4, \mathrm{p}=0.558)$ according to the number of inhabitants per settlement among the respondents.

Figure 3

Respondents to the online survey based on the settlements' tax capacity

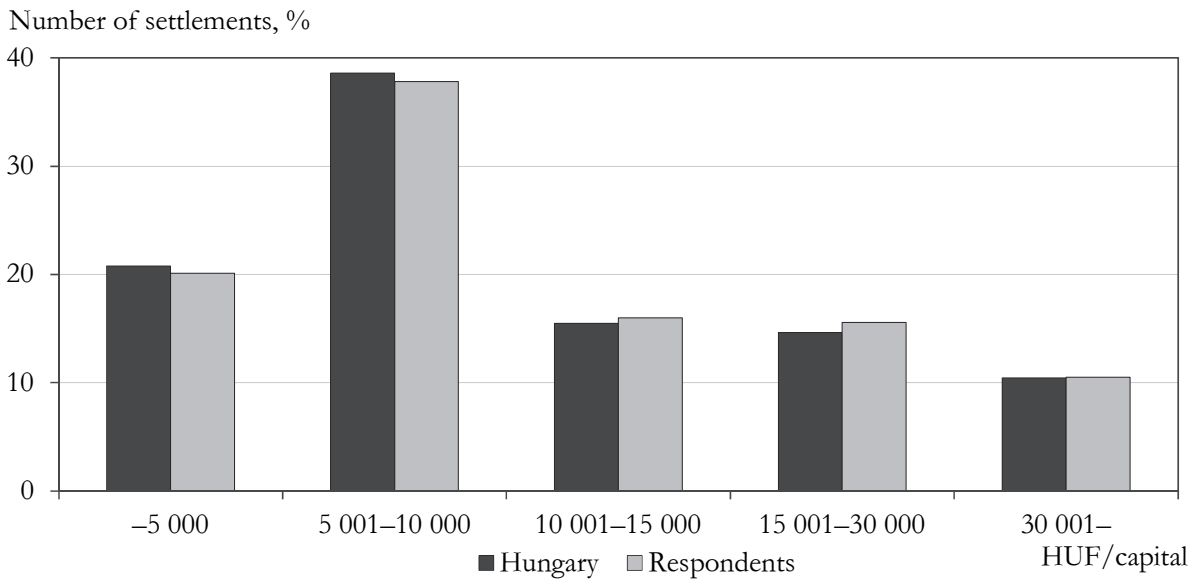

Source: Ministry of the Interior, ÖFFK II.

Based on the fit test, this test dimension can also be considered representative (Chi-square $=2.82, \mathrm{df}=4, \mathrm{p}=0.588$ ).

Hereinafter the research results are presented in detail.

\section{Theoretical background and literature review}

Despite the real or perceived balancing role of the use of Internet-based ICT tools, there are currently significant economic and social inequalities. This digital divide is fundamentally caused by differences in ICT access among different social groups (Mészáros-Jakobi 2013). Factors limiting ICT access include economic ones, such as cost; infrastructural ones such as networking; social ones, such as a low level of education; and cultural ones, such as a lack of exemplary groups to follow (Szarvák 2004). It is clear that an adequate level of modern administrative services is also influenced by the factors above, and lower quality of service is expected where these factors become unfavourable. In Hungary this occurs on the peripheries where, for historical reasons, there is no large city along the state border, as Pécs, Szeged, and Debrecen (Tagai et al. 2018). The extent to which Internet service depends on physical, geographical space is well-illustrated by Jakobi (2017) who analysed the connections of one of the Internet social networks. It was revealed that the majority of cyberspace connections followed the public road network pattern existing in physical reality, for example, around mountains and lakes.

Regional Statistics, Vol. 10. No. 2. 2020: 206-227; DOI: 10.15196/RS100212 
The most complex manifestation of social factors affecting the quality of services, including public administration, is creativity. Its spatial distribution in principle also determines the quality of electronic services. According to a complex study, NE-Hungary, SW-Transdanubia, SE-Great Plain, that is, the peripheries are in the most unfavourable position at the district level in terms of creative professionals and enterprises (Jeney-Varga 2016). Another social aspect is the extreme manifestation of deviance, namely, the spatial distribution of the number of suicides, where the areas of low creativity in the peripheries exhibit the highest proportions of suicide (Bálint-Elekes 2016). After such geographical considerations, let us examine the theoretical foundations of a specific municipal-level ICT survey.

The multi-threaded megatrends (e.g. globalisation, digitalisation, big data, networking mobilisation, the growing role of online communities, and the blurring of generational boundaries) are fundamentally changing more and more areas. The development of these trends significantly impacts public administration. The advent of the Internet in the mid-1990s in the field of government and administration made the use of electronic channels increasingly widespread. Front-office interfaces in the e-government approach offer a wide range of services, on a growing number of platforms. In addition, the concept of government can now be linked not only to state governments and government actors, but also to external actors, for example, economic and civil society actors, and citizens themselves (Betz-Kübler 2013).

Web 2.0 technologies $^{2}$ and social media offer an opportunity to advertise the intentions of individuals and traditional and emerging interest groups, to manage affairs, to handle ordinary or extraordinary events, and to initiate community actions. In the 2020s, open government discourse intensified, and these technologies became the focus of public and economic policies. With the spreading of mobile devices, these technologies are offering an ever-widening availability for users. At the same time, communication in virtual space is also becoming an ideal tool for public administration and government actors. ${ }^{3}$ Social community media help in making targeted communication and (public) policy materials more understandable and to filter individual opinions for strategic purposes. Public administration can provide in this way a good-quality, customer-friendly, interactive and innovative public service.

${ }^{2}$ Web 2.0 technologies constitute a group of technologies optimised for community use, which facilitate information sharing, networking, and community building in the virtual cyberspace.

${ }^{3}$ Social media is a collective name for interfaces based on mobile and web technologies that enable interactive, multimedia, and multimodal, and one-to-one, one-to-many, or many-to-many communication in real time, regardless of location. Social media content is shared by users and often generated by them (or shared from other media interfaces). It can be, for example, collaborative projects (like Wikipedia), blogs (like blog.hu), content communities (such as Filckr and YouTube), social sites (such as Facebook, LinkedIn, and Myspace), virtual game worlds (such as Farmville), virtual social worlds (such as VirtualPlanet 3D administration). There are also regionally popular spaces like Naver apps in Korea, QZone and Weibo-leading in China, Orkut in Brazil, or v Kontakte in Russia.

Regional Statistics, Vol. 10. No. 2. 2020: 206-227; DOI: 10.15196/RS100212 
When, for what purpose and how should we use the functionalities available in public spaces? Should we share information of public interest through them, such as in first-generation websites, or should we communicate with institutions with their help? Should we perhaps promote public services, increase customer-side (retail and entrepreneurial) participation, and consider them as a tool for crisis communication? Experience to date shows that most Organisation for Economic Co-operation and Development (OECD) countries view community spaces as extra channels of communication (Mickoleit 2014). In many cases, we can witness the late response of the government and state administration in these platforms. ${ }^{4}$

Individuals' online petitions, community-developed mobile apps, crowdfunding ${ }^{5}$, and other community actions are common and they can move political events from virtual space to real space; for example, a call made in social media can turn into an actual demonstration in only a few hours. ${ }^{6}$

The Hungarian public administration is adapting to the mass use of the Internet with a significant time lag. In the current situation, the majority of local governments cannot perform their obligations of statutory information and access to information. They are only exposed to the knowledge of their own ICT institutions or to that of their ICT partners. Legislation provides the right to information, self-determination and the freedom of information in Act CXII of 2011. The Act, however, has not yet been adapted to the new channels either; for example, most of the offices still use the Web 1.0 system.

The government and administration are facing an ongoing learning process. The demand, which needs to be tailored to customer needs, imposes additional tasks on the administration. It is essential to know and follow the megatrends, and consciously plan, design, and develop systems so that the quality of services can adapt to the citizens' growing expectations. This requires a marked change in approach, the central elements of which should be adaptation, the development of the capacities needed to perform new functions, and the creation of new communication strategies in administration.

\footnotetext{
${ }^{4}$ Out of the 25 OECD countries surveyed, only 7 had a social media strategy in 2013. Although the governments of all these countries studied used some kind of community solution, only 10 of the 25 countries applied community media apps in their internal communication processes. In addition, only 5 countries measured the success of their strategies and the impact of social media.

${ }^{5}$ Crowdfunding is a form of community funding in which think tanks generate the money needed to launch a product or service on their own site or on a site specifically dedicated to fundraising (e.g. kickstarter.com and indigogo.com). The success of such campaigns crucially depends on the presence (number of appearances and shares) on related social sites. The concept originally covered business initiatives but now administrative or civil initiatives are not uncommon either (e.g. crowdrise.com and justgiving.com).

${ }^{6}$ The Internet is starting to replace the employer-employee matching function of employment centres, and these institutions are increasingly trying to open the door to training. In Germany, local employment centres have collaborated with a community portal named Xing, which includes job searches and job offers.
}

Regional Statistics, Vol. 10. No. 2. 2020: 206-227; DOI: 10.15196/RS100212 


\section{The alternative nature of community space}

The use of traditional websites, mainly for one-way communication, is dominant in most parts of Europe. Community spaces provide easy, fast, and direct access to reduce digital inequalities. They also play a significant role in interactivity and therefore, they are important for public administration. The benefits of community spaces are seen in the strong interactions, user-centricity, easy interface and service management, and great added value for users (Wirtz et al. 2010). Yet, in most government strategies, even if they include the use of a community space, its aim is only the alternative dissemination of information, the improvement of communication, and not an increase in public consultation and active participation of the inhabitants.

In the Nordic countries as well as in Germany and Austria, there is no correlation between the use of social media and an individual's education. In Spain, the United Kingdom, Poland, Portugal, Turkey, and Greece however the use of social media is much more common among those with higher education (Mickoleit 2014). In Hungary, according to the Eurostat 2017 report, 83\% of the population aged 16-74 use social media applications. This is the highest value among EU countries. Among regular users women, people with lower education and those under 30 are overrepresented in the population.

The age groups with the highest use of community spaces show very low activity in public and political affairs. (This behaviour can be seen in their willingness to participate in elections as well.) At the same time, it is also an important indication that the young generations (the $Z$ and Alpha generations) already prefer communication through social media even in instant messaging to traditional channels of communication such as e-mail (Howard 2013).

In Central Europe, there are two of the Visegrád Group, Visegrád Four, or V4, is a cultural and political alliance of four Central European countries: the Czech Republic, Hungary, Poland and Slovakia (V4 countries) that face similar problems in public administration due to their similar historic development: the Czech Republic and Slovakia. There, investigations found territorial inequalities in the quality of municipal services. They concluded that the largest problem is the lack of the application of the theory of economies of scale. Consequently, the smaller a local government, the lower its efficiency is. Matějová et al. (2017) analysed the effects of economies of scale on the administration at the local level, regarding the local government offices' amalgamation in the South Moravian region in the Czech Republic. They showed that the existence of municipalities that are too small results in inefficiencies in the services provided. One can conclude that the economies of scale in small municipalities are not very good but the Applications Service Providing (ASP)-like maintenance of the IT infrastructure could improve them, thus allowing a stronger focus on local services and their customisation. Again, that was

Regional Statistics, Vol. 10. No. 2. 2020: 206-227; DOI: 10.15196/RS100212 
one of the reasons we focused our research on the IT facilities of local governments.

Some very well-established studies have been conducted in order to solve the problem of territorial fragmentation of administration in the Czech Republic. In addition to finding that economies of scale are an indicator of a reshaping of the office size in local governments, they discovered that municipal expenditures on selected public services determined a municipality's optimal office size for the services analysed (Nemec et al. 2016). Finding the right size for territorial consolidation of administration has long been a serious problem but because of fears of violating self-governments' autonomy, this has been a sensitive issue since the establishment of municipalities. The solution may be that without violating autonomy, it is necessary to reconsider what tasks the local government should undertake and which tasks should be delegated to higher, micro-regional, regional, or central levels. We believe that IT-supported services could be run in an ASP system on some regional level to obtain improved economies of scale. This was another reason we investigated municipal IT access and facilities. This opinion is further strengthened by the findings of another study from the Czech Republic: a significant fragmentation of regions, and municipalities in particular, is associated with the fact that small municipalities face financial difficulties in their development, to which their mayors respond by cumulating mandates and forming micro-regional interest associations (Jüptner-Kruntorádová 2015).

The basic assumption we relied on in this study includes the regional distribution of unemployment (Alpek et al. 2018, 2019a, b, Demeter 2020). We assumed that the distribution of the worst e-government facilities would coincide with the districts showing the lowest values in the proportion of individuals with higher education in the population (Kanó et al. 2017). This assumption is to be verified through a strong correlation. There is another social aspect, the impact of which may also influence the regional inequalities in the facilities of electronic front office services: the crime rate. This is also significantly higher in the settlements that we assume as administratively disadvantaged in terms of e-government facilities. This may be because a continuous police presence is missing in these small settlements since they have no police stations or guardhouses. Mátyás et al. (2019) showed that the average number of crimes in settlements with no police station or guardhouses was higher in the districts where we expected poor e-government front office services.

Finally, it should not be overlooked that the factors affecting the success of online public services in new media ${ }^{7}$ include quality and user-friendliness. The greatest social satisfaction can be achieved if in addition to digital information and services, certain analogue services continue to be available; personal contact and

\footnotetext{
${ }^{7}$ New media is the overarching name of the type of media created through digital network communications (internet, interactive digital television, cellular data transmission, etc.), characterised by interactivity among and the actions of consumers (or consumer communities) shaping the content.
}

Regional Statistics, Vol. 10. No. 2. 2020: 206-227; DOI: 10.15196/RS100212 
direct communication remain important in cases of more complex issues and topics (Federal Office for Building and Regional Planning - Bundesinstitut für Bau-, Stadtund Raumforschung 2017). However, the existence of offline services is also justified by generational differences.

\section{Research results}

The fact that the citizens of the state must be served on equal terms and conditions across the entire country was already stated in the Public Administration Procedure Act (Act IV of 1957), and since then, all procedural codes have declared it. However, as time passes and development advances, digital inequality can be traced in public administration as well. Therefore, the portfolios of public services are becoming completely different in different parts of the country.

By mapping our research data, we observed particular regional patterns in the distribution of the quality of administration that are very clear. These were compared with the patterns in economic performance factors (such as tax capacity and purchasing power and its change), urbanisation types, the population, the distribution of the most disadvantaged urban areas, the number of segregations and the presence of Roma ethnic groups (as the most disadvantaged regions from the aspect of digital equality). Then we examined the overlaps of these regional patterns. In order to study the relationships among the most disadvantaged economic regions (the most disadvantaged economic regions - DER) and the ethnic regions, we used the research methods in Kadét-Varró (2010) and Lukács (2017).

1) We observed significantly worse results in regions with small settlements than in regions with isolated farms or rural areas although all these types of regions have a low urbanisation level. Naturally, urban settlements with a relatively high urbanisation level exhibited the opposite results. Cserehát (in North Hungary) and Ormánság (in South Transdanubia) showed extremely poor results.

2) The DER - in line with our preliminary expectations - showed significantly weaker values than those of settlements with good or increasing purchasing power and tax capacity.

3) The presence of the Roma ethnic group in the population and the number and location of their settlements also coincided with our expectations for the results in all research dimensions. However, these characteristics did not always reveal the worst performers. In general, public administration front offices operate poorly in settlements with weak economic performances (although, as mentioned above, public administration is supposed to operate at the same level of development, regardless of location.) Pénzes et al. (2018) found that the Roma population increased by more than $20 \%$ in the Bátonyterenye, Encs, Heves, Ózd, and Sellye districts and this agrees with

Regional Statistics, Vol. 10. No. 2. 2020: 206-227; DOI: 10.15196/RS100212 
our findings: these districts are the worst performers in terms of egovernment facilities.

In the following, we present five dimensions of the study, from which the backlog degree of an administrative front office compared to the national average can be derived for several administrative districts.

Figure 4

Estimated proportion of computers older than three years in each municipality

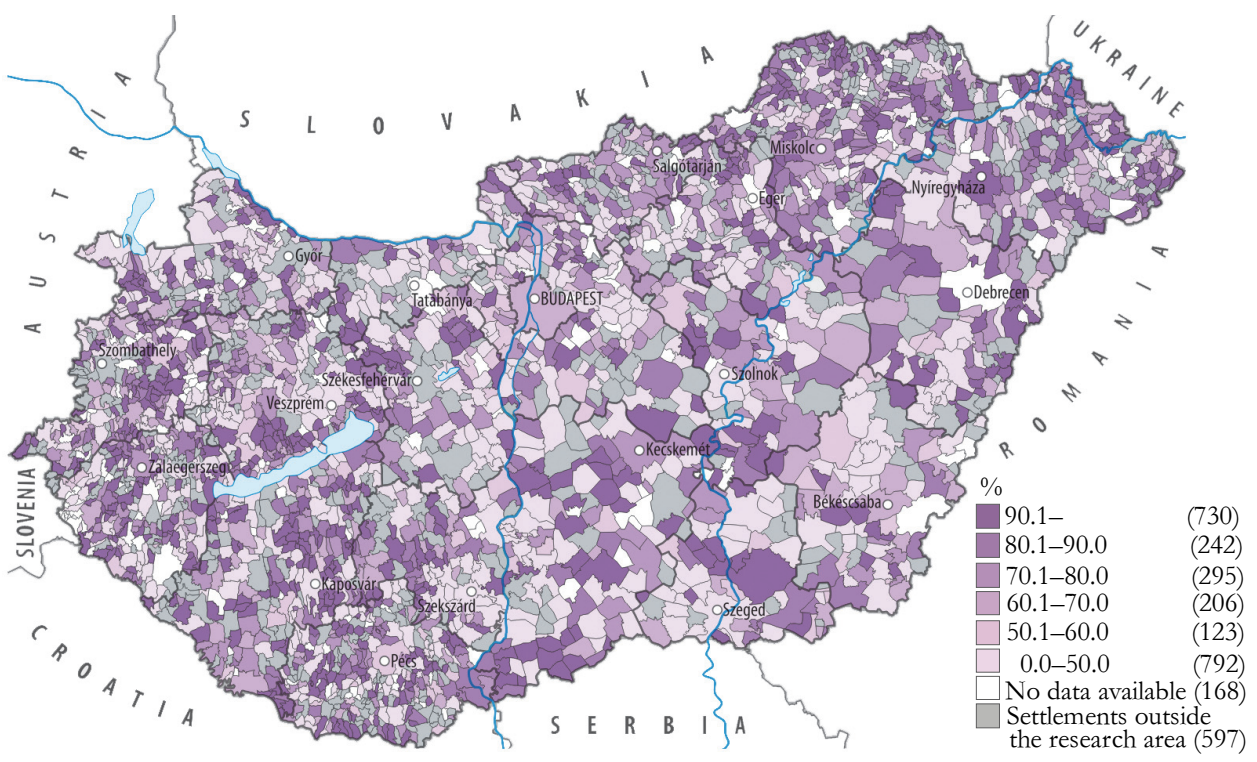

Source: Data of the Ministry of the Interior based on ÖFFK II. 2018. Analysis by the authors.

Based on the age of computers we can infer directly the state of the IT service infrastructure, the innovation potential, and the development of the resulting service portfolio. Three years is considered the limit because this is the time it takes to write down the book value of computers to 0 , and after three years the machine requires replacement. In the municipalities where the proportion of computers older than three years is high, obsolescence of the machines, limitations to the obligatory local government tasks and a low innovation potential can be assumed. As a consequence, these local governments have to prefer the traditional (offline) way of contacting customers. (Therefore, in most cases, the first question determines the answers to the following questions.)

As expected, based on the economic data, the urbanisation structure and the number of settlements, we see poor values in the DER, mostly in the NE regions of the Borsod county districts (e.g. Szikszó district: $85.1 \%$; Putnok district: $88.6 \%$ ), in the Szabolcs-Szatmár-Bereg county district (e.g. Vásárosnamény district: 76.7\%; Csengeri district: 90\%), several in the Baranya county district (e.g. Hegyháti district:

Regional Statistics, Vol. 10. No. 2. 2020: 206-227; DOI: 10.15196/RS100212 
70.8\%; Sellye district: 71.7\%). In North Hungary, poor values are also observed in the Nógrád county districts (e.g. Salgótarján district: 75.3\%; Szécsény district: $73.3 \%$ ), and in Southern Transdanubia, in the Somogy county districts (e.g. Barcs district: $84 \%$; Nagyatád district: $80.8 \%$ ). However, we were surprised by the poor results in some districts in the Balaton Uplands outside the DER (e.g. Fonyód district: $77.4 \%$ ) and some of the Zala county districts (e.g. Letenye district: 76\%). While the national average is $52.1 \%$ for settlements with less than 1,000 inhabitants, the proportion of computers older than 3 years is even higher than $70 \%$ in the above listed areas. Thus, in all the listed districts there are at least three brokendown or over-used computers out of four that are prone to failure, endangering the continuity of office work. If we consider the population, geographical position, proportion of the Roma population and purchasing power in the listed settlements, we observe that the population and geographical position are the most decisive factors, resulting in low purchasing power as well. A geographical location along the borders, only accompanied with a low population, creates a disadvantaged position, which may be exacerbated by a higher-than-average proportion of the Roma population and the population over 65 years old (though the latter two aspects have the exact opposite effects). This is how the 'administratively disadvantaged regions' are being formed (hereinafter referred to as Administratively Disadvantaged Regions [ADR]), where the ability to receive customers is limited (either due to the poor facilities of the office or a large number of customers). We can see a variety of such ADR, in terms of their composition. The worst eight districts in terms of infrastructural facilities are presented in Table 1 below.

Table 1

Proportion of computers older than three years, settlement population, Roma population, and purchasing power in the worst eight districts in Hungary

\begin{tabular}{l|c|c|c|c}
\hline \multicolumn{1}{c|}{ District } & $\begin{array}{c}\text { Population, } \\
\text { capita }\end{array}$ & $\begin{array}{c}\text { Roma population, } \\
\%\end{array}$ & $\begin{array}{c}\text { Purchasing power, } \\
\text { EUR }\end{array}$ & $\begin{array}{c}\text { Computers older } \\
\text { than 3 years, \% }\end{array}$ \\
\hline Nagyatád & 833 & 18.7 & 2,970 & 80.8 \\
Siklós & 765 & 6.2 & 3,511 & 81.9 \\
Edelény & 740 & 15 & 3,637 & 82.0 \\
Záhony & 1,772 & 10.9 & 3,253 & 82.0 \\
Barcs & 938 & 14.3 & 3,000 & 84.0 \\
Szikszó & 804 & 16.9 & 3,101 & 85.1 \\
Putnok & 709 & 9.4 & 3,589 & 88.6 \\
Csenger & 1,428 & 10.3 & 3,078 & 90.0
\end{tabular}

Source: Data of the Ministry of the Interior based on ÖFFK II. 2018 and KSH data 2018. Analysis by the authors.

Regional Statistics, Vol. 10. No. 2. 2020: 206-227; DOI: 10.15196/RS100212 
Figure 5

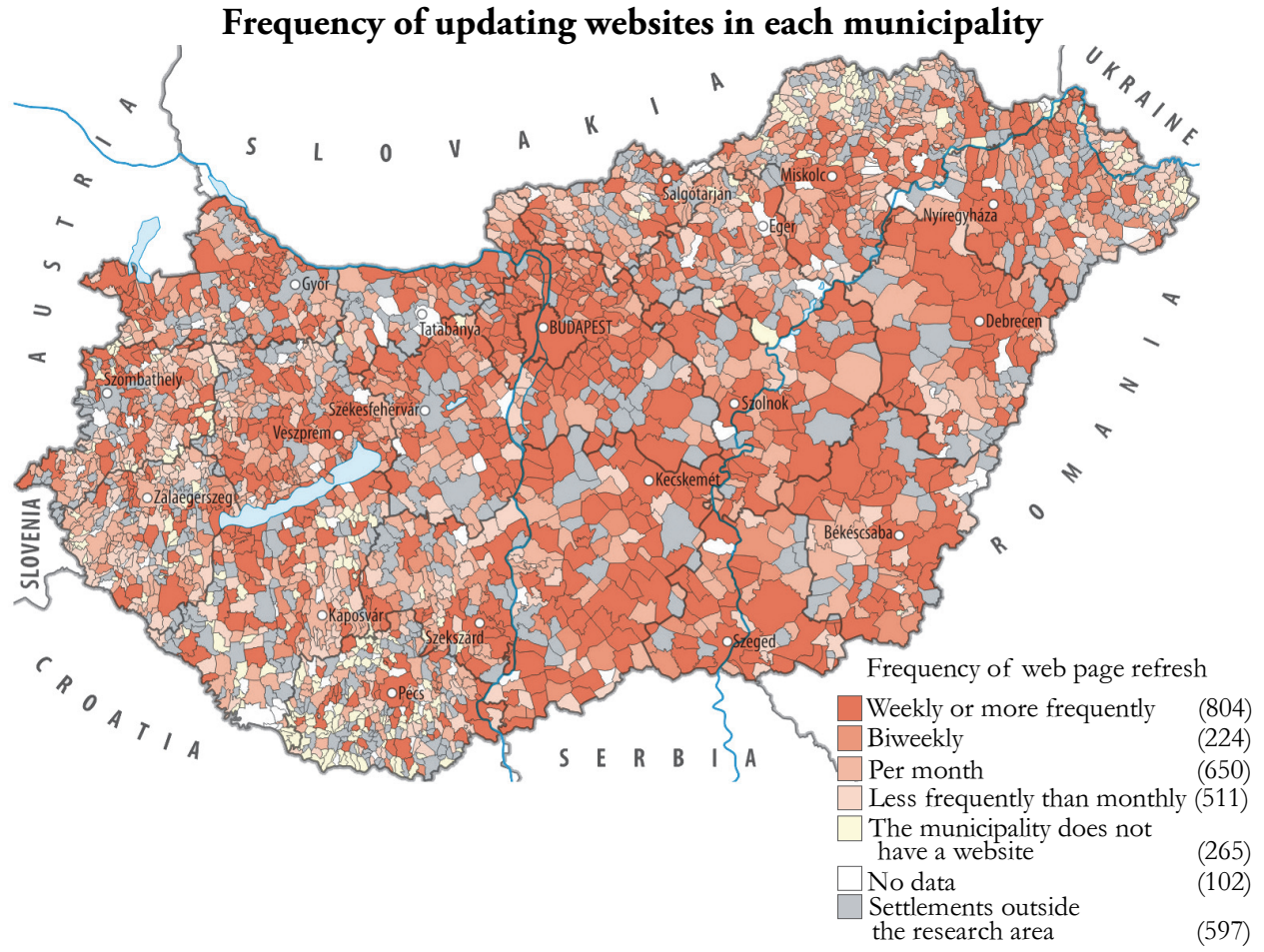

Source: Data of the Ministry of the Interior based on OFFK II. 2018. Analysis by the authors.

The frequency of website updating shows how many resources the municipality devotes to informing customers properly. Minor settlements with only a few dozen inhabitants would be expected to update their website news at least once every two weeks as this shows that the municipality is active. Monthly or less frequent updates (or ad absurdum, the lack of websites) imply that customers are not properly informed and cannot use electronic public services based on the websites. On average, 14.1\% of the settlements with fewer than 1,000 inhabitants update their online information at least weekly, $7.7 \%$ of them do it every two weeks, and $28.6 \%$ of them do it monthly (i.e. almost $50 \%$ of them update the information less frequently). For settlements with a population between 1,000 and 5,000 people these proportions are $44.7 \%, 11.8 \%$, $25 \%$, and $18.6 \%$, respectively. Thus, small-village areas are likely to either be invisible online or have websites with outdated information.

This is reflected in Figure 3, which shows the municipalities. Many of the minor ones mostly located along the borders exhibit worse values than those of municipalities with monthly updates. The settlements along the River Drava and the Croatian and Slovenian borders; in Southern Transdanubia, in Somogy and Zala counties; in NE Hungary close to the Ukrainian and Romanian borders; and in

Regional Statistics, Vol. 10. No. 2. 2020: 206-227; DOI: 10.15196/RS1002 12 
Northern Hungary, in Borsod county along the Slovakian border are barely visible in the digital space. The smaller a municipality is, the fewer resources it can devote to functions outside the mandatory tasks, especially if it cannot be financed by any external sources (e.g. if its tax capacity is low) or if it does not have the necessary human resources.

Table 2

Frequency of updating websites in the districts exhibiting the worst situation

\begin{tabular}{l|c|c|c|l}
\hline \multicolumn{1}{c|}{ District } & $\begin{array}{c}\text { Population, } \\
\text { capita }\end{array}$ & $\begin{array}{c}\text { Roma } \\
\text { population, } \\
\%\end{array}$ & $\begin{array}{c}\text { Purchasing } \\
\text { power, EUR }\end{array}$ & Average website refresh rate \\
\hline Hegyhát & 465 & 14.6 & 3,197 & Less frequently than every three months \\
Sellye & 383 & 24.5 & 2,986 & Less frequently than every three months \\
Szentlőrinc & 795 & 11.9 & 3,565 & Less frequently than every three months \\
Siklós & 765 & 6.2 & 3,511 & Less frequently than every three months \\
Barcs & 938 & 14.3 & 3,000 & Less frequently than every three months \\
Putnok & 709 & 9.4 & 3,589 & Less frequently than every three months \\
Szigetvár & 574 & 10.6 & 3,038 & Every three months \\
Letenye & 585 & 12.6 & 3,320 & Every three months
\end{tabular}

Source: Data of the Ministry of the Interior based on ÖFFK II. 2018. Authors' calculations.

All of the worst eight districts have small villages, with a significantly higherthan-average proportion of Roma population and settlements, and the lowest purchasing power (merely over two-thirds of the national average).

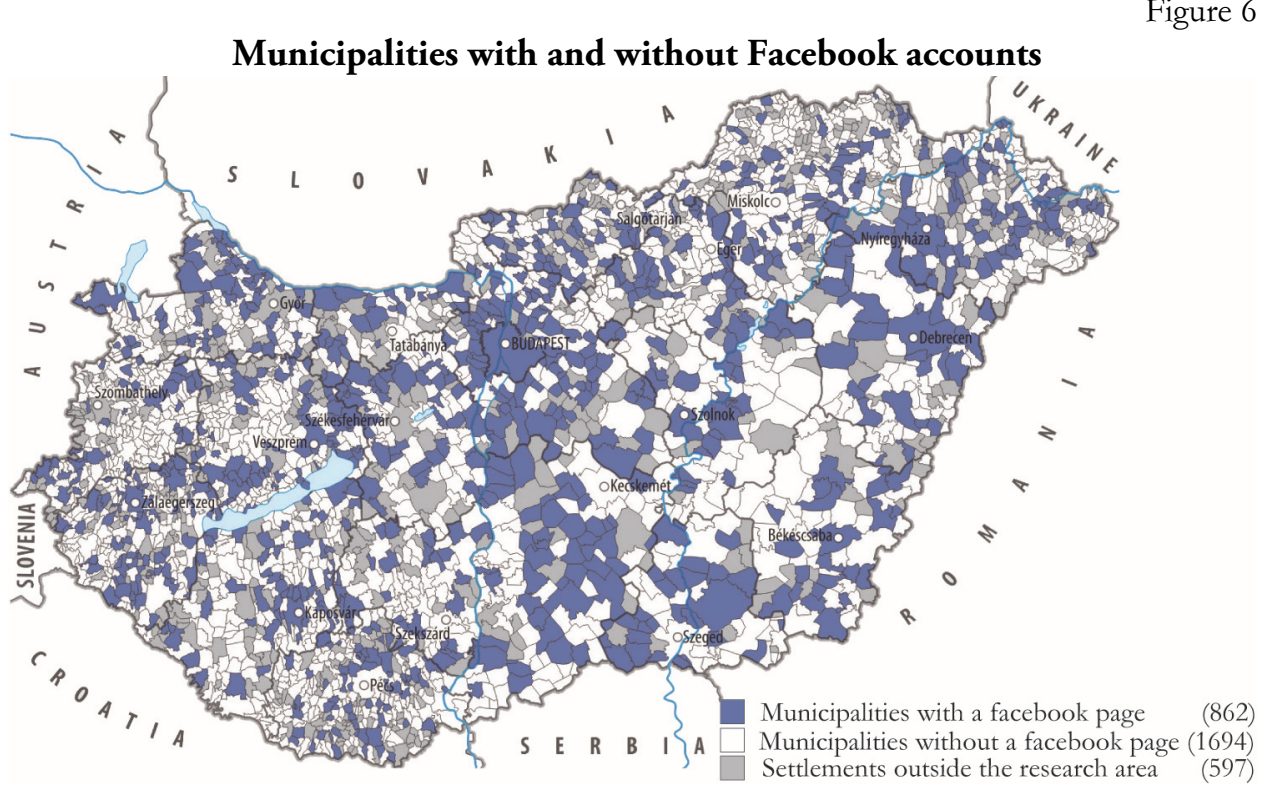

Source: Data of the Ministry of the Interior based on OFFK II. 2018. Analysis by the authors.

Regional Statistics, Vol. 10. No. 2. 2020: 206-227; DOI: 10.15196/RS100212 
When examining online community spaces, we observed a negligible number of cases where Twitter and Instagram were being used. The few dozen applications of these two platforms (36 for Twitter and 51 for Instagram) deserve no further explanation. Overall, the great majority of Hungarian municipalities have not yet recognised the advantages and real functionalities of these channels in public administration. However, one out of three responders is already an active Facebook user. Out of the settlements with fewer than 1,000 inhabitants 30.9\% use Facebook; of those with 1,000-5,000 inhabitants, $44.8 \%$ use Facebook. In addition, the pattern in municipalities with a Facebook account differs from the previous ones in several aspects. It is not the presence of rich and developed urban areas that is unusual but that of settlements that stand out because they have had a poor performance in the previous surveys, as shown in Figures 4 and 5. Therefore, it seems that these municipalities are trying to overcome their unfavourable endowments by seeking an interface to communicate with customers. However, it is surprising that the developed parts of NW Transdanubia (Kisalföld, excluding the vicinities of Györ and Esztergom) do not have online community spaces yet, similarly to the settlements in the vicinity of Debrecen (the Nagykunság region).

\section{Proportion of Facebook accounts in the eight districts with the worst results}

\begin{tabular}{l|c|c|c|c|l}
\hline \multicolumn{1}{c|}{ District } & $\begin{array}{c}\text { Population, } \\
\text { capita }\end{array}$ & $\begin{array}{c}\text { Roma } \\
\text { population, \% }\end{array}$ & $\begin{array}{c}\text { Purchasing } \\
\text { power, EUR }\end{array}$ & $\begin{array}{c}\text { Proportion of } \\
\text { Facebook } \\
\text { accounts, \% }\end{array}$ & $\begin{array}{c}\text { Average website refresh } \\
\text { rate }\end{array}$ \\
\hline Nagyatád & 833 & 18.7 & 2,970 & 0.0 & Every three months \\
Csenger & 1,428 & 10.3 & 3,078 & 10.0 & Every three months \\
Marcali & 976 & 11.2 & 3,689 & 12.9 & Monthly \\
Edelény & 740 & 15.0 & 3,637 & 15.4 & Every three months \\
Sellye & 383 & 24.5 & 2,986 & 17.9 & Less frequently than \\
Szikszó & 804 & 16.9 & 3,101 & 18.8 & Every three months \\
Devecser & 503 & 7.2 & 3,595 & 20.0 & Monthly three months \\
Nyírbátor & 2,413 & 12.2 & 3,294 & 21.4 & Monthly
\end{tabular}

Source: Data of the Ministry of the Interior, ÖFFK II. 2018. Authors' calculations.

If we rank the administrative districts by the extent to which they provide information (primarily on Facebook, secondarily on their websites), we observe that districts are neglecting this aspect across the entire country but mostly in Somogy, in Szabolcs-Szatmár-Bereg, and in Borsod, Veszprém and Baranya counties. Therefore, the lack of community spaces is a national feature among Hungarian local government offices. This is a serious problem because no alternative connection with customers exists in these districts as websites do not provide meaningful information either. As a result, they are completely invisible in virtual space.

Regional Statistics, Vol. 10. No. 2. 2020: 206-227; DOI: 10.15196/RS100212 


\section{Use of Facebook features in Hungarian municipalities}

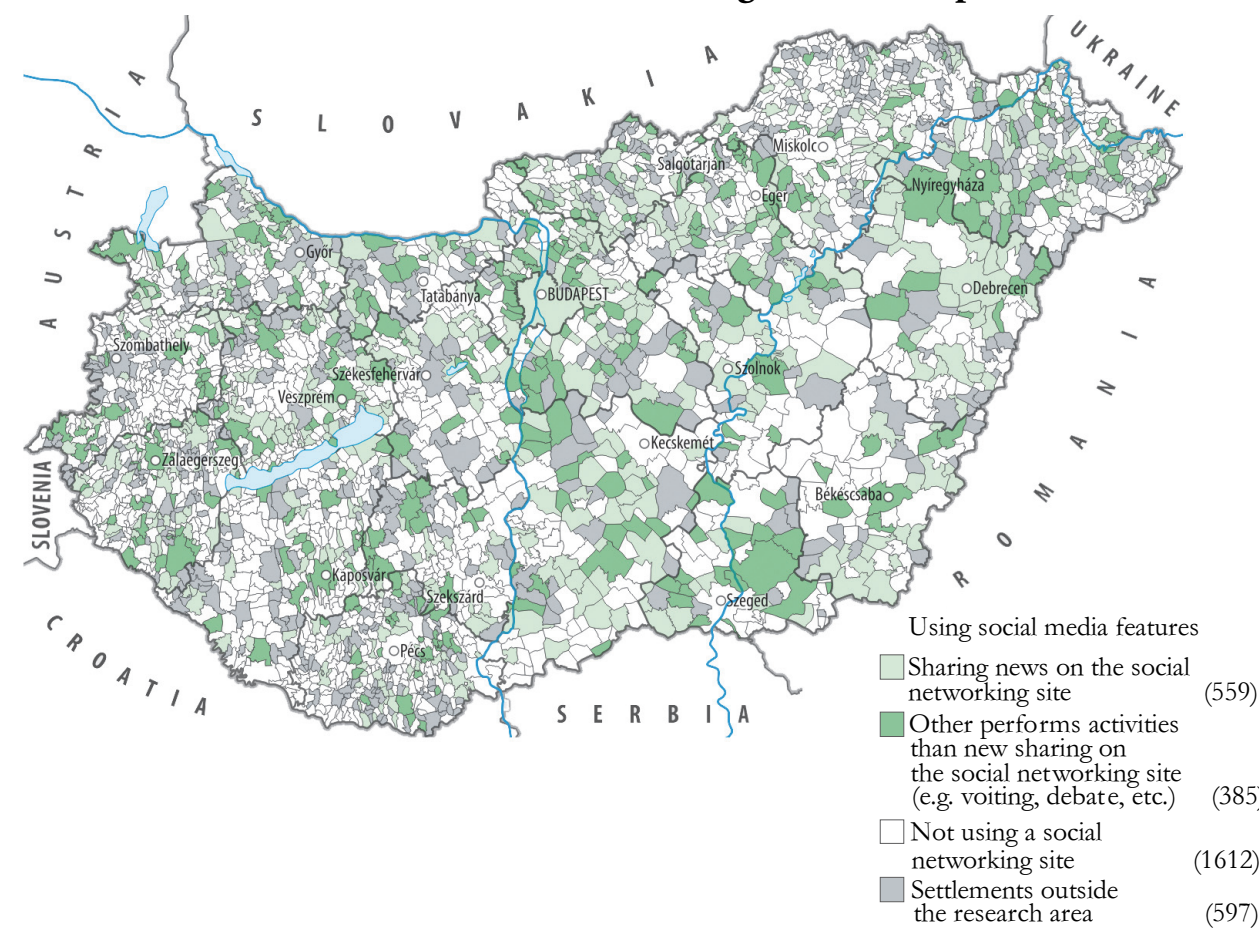

Source: Data of the Ministry of the Interior, ÖFFK II. 2018. Analysis by the authors.

Approximately one-third of the municipalities use Facebook, which can be a source of some hope for ICT development. However, we have to note that meaningful use (regarding the functionalities indicated in the introduction of this paper) occurs in one-tenth of the local government offices only. On the other hand, two-thirds of Facebook activities are limited to publishing news only. The municipalities showing substantial Facebook activities (beyond providing news) are difficult to typify: we can find good solutions almost everywhere, regardless of the financial background, development dynamics, settlement size, number of settlements and so on. It is assumed that the preparedness and attitude of the official human resources may be the decisive factors in this matter. It seems unnecessary and impossible to highlight the worst eight municipalities because dozens of them exhibiting a value of $0 \%$ are tied in the last positions.

Regional Statistics, Vol. 10. No. 2. 2020: 206-227; DOI: 10.15196/RS100212 


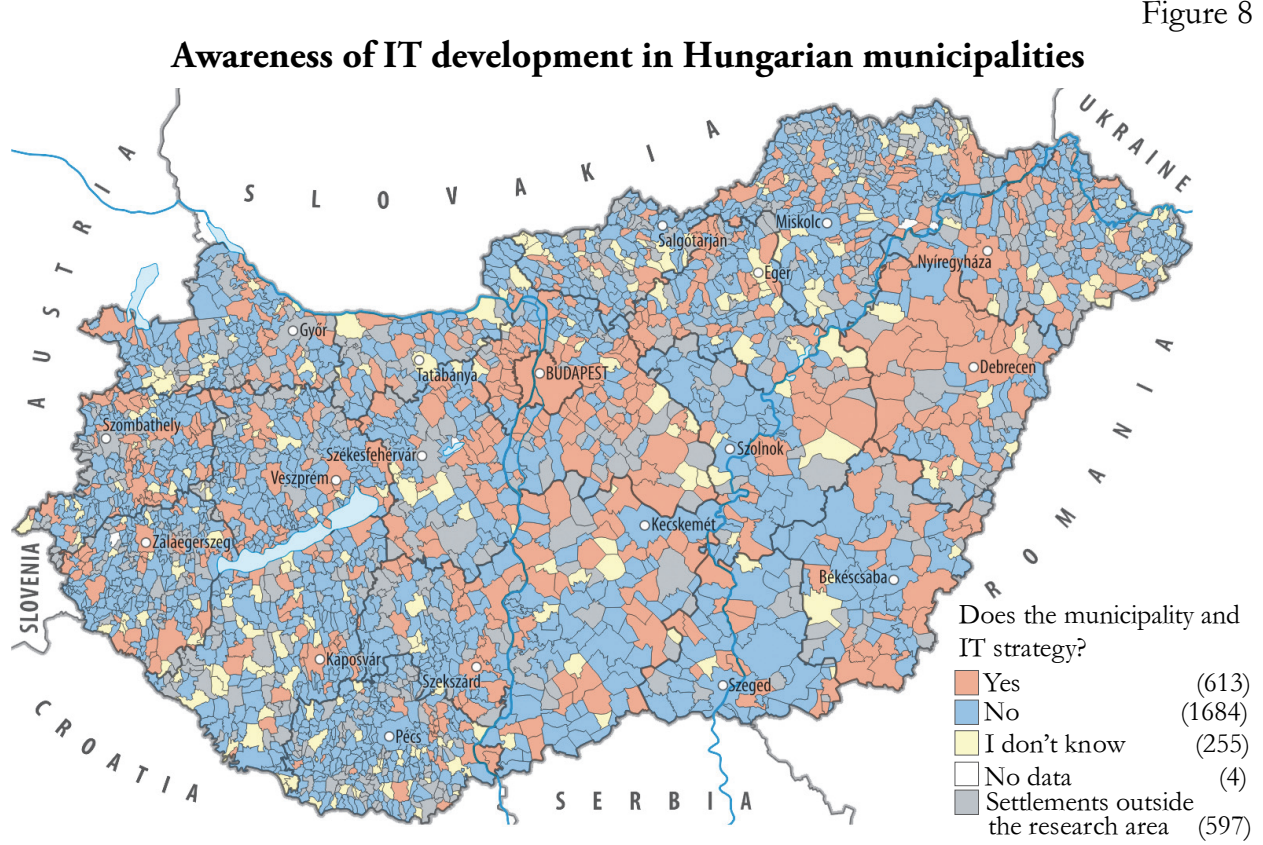

Source: Data of the Ministry of the Interior, ÖFFK II. 2018. Analysis by the authors.

Finally, the attitudes of Hungarian municipalities regarding ICT facilities are also worth examining. From the map in Figure 8, we can see that the number of municipalities with conscious ICT development is very small. Two out of every ten local governments have a strategy for dealing with IT issues. (The proportion of local governments with such strategies in force is $13.6 \%$ for settlements with fewer than 1,000 inhabitants and $29.6 \%$ for settlements with 1,000-5,000 inhabitants.) In other words, $80 \%$ of the municipalities do not see the communication of information as a strategic pillar but as an additional task or burden. It is seen as a utility that assists (or sometimes even hinders) the statutory performance of tasks rather than as a tool that can provide value-added services to customers. Even worse, there are several major towns without a valid IT strategy (only $54.5 \%$ of the major cities have an IT strategy). 
Proportion of valid IT strategies in the worst eight districts

\begin{tabular}{l|c|c|c|c}
\hline \multicolumn{1}{c|}{ District } & Population, capita & $\begin{array}{c}\text { Roma population, } \\
\%\end{array}$ & $\begin{array}{c}\text { Purchasing power, } \\
\text { EUR }\end{array}$ & $\begin{array}{c}\text { Proportion of valid } \\
\text { IT strategies, \% }\end{array}$ \\
\hline Csenger & 1,428 & 10.3 & 3,078 & 0.0 \\
Devecser & 503 & 7.2 & 3,595 & 0.0 \\
Pécs & $894 \mathrm{a})$ & 8.1 & 4,794 & 0.0 \\
Szentlőrinc & 795 & 11.9 & 3,565 & 0.0 \\
Sellye & 383 & 24.5 & 2,986 & 3.6 \\
Hegyhát & 465 & 14.6 & 3,197 & 4.5 \\
Szigetvár & 574 & 10.6 & 3,038 & 5.3 \\
Nagyatád & 833 & 18.7 & 2,970 & 5.9
\end{tabular}

a) Excluding the city of Pécs itself.

Source: Data of the Ministry of the Interior ÖFFK II 2018 and KSH data 2018. Authors' calculations.

In addition to the aforementioned eight districts, there are dozens of districts with poor results regarding IT strategies. They do not seem to know their potential needs or the opportunities to expand their strategies. As a result, no rapid catchingup can be expected in the short and medium term. The differences between the relatively well-developed and less-developed districts will increase.

However, these settlements will probably not focus on the modernisation of their administrative front-offices until they are required to do so by law and have the necessary means to do it. As long as this is the situation in a significant part of Hungarian settlements, we can hardly see mass adoptions of the social media functions mentioned in the introduction. Therefore, compared to developed countries, Hungary lags behind in terms of the quality of administrations, and regional inequalities occur within the country (see the regional overlaps in the tables presented above). These regional inequalities are as sharp as if the municipalities at the two extremes were located in two different countries. Since $70-80 \%$ of the Roma population live in deep poverty and their capacity to assert their interests is also low, the administrative services in their regions are shrinking. This further deepens their segregation and worsens both the opportunities for those living there and the efficiency of the administration.

The government is taking unifying and at the same time centralising measures against the abovementioned dangers and inequalities; however, the costs, efficiency, and implementation rate of these measures have not yet been proven by time. 


\section{Conclusions}

After the spread of the mobile internet in the 2010s, the prevailing assumption was that e-government, and as part of it, the spread and dominance of local egovernment services, would face a generational issue. It was assumed that as the young generations grew up, they would naturally use mobile internet applications, and municipal services would be offered exclusively through ITC tools. This would occur in a way similar to how the typewriter naturally replaced handwriting, and then the typewriter was replaced by the computer. Researchers believed that the establishment of e-government was not primarily hampered by a lack of knowledge or technology but motivation. The tax and statistical administration services where e-government was required by law showed $100 \%$ penetration among users. Law is kind of an external, coercive motivation, but internal motivation, namely that customers demand and prefer electronic administration, has lagged. The regional data published here shows that in the late 2010s in a relatively developed Central European country such as Hungary, which is in the middle of the ranking of EU countries in terms of the e-government readiness index, is lagging in the modernisation of municipal front office customer services. As mentioned above, a very high percentage of municipalities participated in the survey. This was the largest volume of municipal surveys to date, so it gives a fairly realistic picture.

The most important of our findings is that while a wide range of online mobile applications do not appear in municipal administration, this is not a generational issue. The digital divide is reproducing itself. The reason is that outdated and cumbersome municipal services are more an economic, infrastructural, and social issue than an unresolved ICT shortage issue. In the NE, SW and SE peripheries of Hungary, where the flow of capital is small, the road network is insufficient and social segregation and deviance are a problem, web applications are not used in the operation of local governments and public administration is not being modernised in a large extent. That is why the government's efforts to raise the development level of public administration across the country, including local governments, have been unsuccessful so far, especially on the periphery and in places with social problems, poverty and low levels of education, as well as a high proportion of Roma population. Local administrative services cannot be developed and modernised without economic, infrastructural, and social funds, similar to the way that no house can be built without fundament. Widespread use of ICT occurs in large cities, including in the areas of municipal services; in underdeveloped areas, this can only be achieved if similar economic, infrastructural, and social conditions emerge. Our findings agree with those of another recent study, Faluvégi (2020): the least developed micro-regions coincide with the least developed districts in terms of egovernment front office facilities.

Regional Statistics, Vol. 10. No. 2. 2020: 206-227; DOI: 10.15196/RS1002 12 
Since our starting point of methodology was the Slovenian initiative, it would be worth noting that in Slovenia studies also tried to understand the reasons for the relatively poor implementation of electronic government tools as a principle for improving bureaucratic processes. Survey results in Slovenia showed a general lack of motivation, measured as the ignorance of technology potentials as well as that of existing threats. Their main argument was that the lack of motivation blocks most reform attempts by creating a negative human environment (Pinterič 2020). Our results prove that in addition to the lack of motivation, the totality of regional inequalities play an intensifying role in slowing down technological transfer into the ICT development of local municipalities. What is interesting from a regional development point of view is that the districts showing a relative low ICT penetration in local government offices reflect the physical location of technological and social infrastructure. This is why the lowest ICT penetration in e-government can be found in the inner and outer peripheries of Hungary. A major study on two other countries in the Central European region, with similar dimensions as Hungary, was Nemec et al. (2008). They examined the demand for benchmarking in public administration bodies in the Czech Republic and Slovakia. It was verified that benchmarking is not regularly or properly used, either in Slovakia or in the Czech Republic. Subjective barriers to its implementation, for example, the lack of accountability, the rent-seeking attitudes of elected politicians, and ineffective public services schemes, were found to be the most important issues. Further, although they found that the situation was slowly improving, the progress was limited by territorial fragmentation. The present study also verifies the need for benchmarking so that territorial differences could be reduced. Continuous monitoring, benchmarking and bench-learning help to measure and bridge the degree of digital, economic, and social inequalities influencing the effectivity of local municipal services.

In this study, out of the 34 questions in our online survey, we addressed only 5 . We did this because these five questions focus on the most characteristic features from which the presence of municipalities in virtual space can be deduced. The rich research materials we obtained are also suitable for exploring further aspects, which we are going to study in the future.

\section{Acknowledgements}

This major municipal study involving 34 online questions, of which we selected 5 items, was funded by the Local Government Coordination Office of the Hungarian Ministry of Interior, grant number KÖFOP-2.3.4-VEKOP-15-2016-00002. This study was the largestscope investigation into local self-governments in Hungary since their establishment in 1990.

Regional Statistics, Vol. 10. No. 2. 2020: 206-227; DOI: 10.15196/RS100212 


\section{REFERENCES}

AlPEK, L.-TÉsits, R.-HovÁNYI, G. (2018): Spatial Inequalities of Disadvantage Accumulation and their Impact on Employability in Hungary Regional Statistics 8 (1): 96-119. https://doi.org/10.15196/RS080104

ALPEK, L.-TÉSITS, R. (2019a): A foglalkoztathatóság mérési lehetőségei és térszerkezete Magyarországon Területi Statisżtika 59 (2): 164-187. https://doi.org/10.15196/TS590203

ALPEK, L.-TÉSITS, R. (2019b): A foglalkoztathatóság térszerkezeti és települési dimenziói Magyarországon Területi Statisz̨tika 59 (4): 381-399. https://doi.org/10.15196/TS590402

BÁLINT, L.-ELEKES, Zs. (2016): Magyarország deviancia térképe előrejelzésekkel. In: TÓZSA, I. (ed.): Humán tér-kép. A bumán és fejlesztéspolitikai tényezốk földrajza Magyarországon pp. 89-137., BCE - PAGEO Alapítvány, Budapest.

BETZ, J.-KÜBLER, H-D. (2013): Internet Governance Springer Fachmedien, Wiesbaden. https://doi.org/10.1007/978-3-531-19241-3

Bundesinstitut für BAu-, Stadt- und RAumforschung (2017): Smart City Charta Digitale Transformation in den Kommunen nachbaltig gestalten Bundesamt für Bauwesen und Raumordnung (BBR), Bonn-Berlin.

Demeter, G. (2020): Estimating regional inequalities in the Carpathian Basin - Historical origins and recent outcomes (1880-2010) Regional Statistics 10 (1): 23-59. https://doi.org/10.15196/RS100105

FALUVÉGI, A. (2020): A magyar kistérségek fejlettségi különbségei Területi Statisætika 60 (1): 118-148. https://doi.org/10.15196/TS600109

Howndo, A. (2013): The What, How and Why of Social Media - A Guide for Local Government, A Report for Sydney Coastal Councils Group Howard Partners Pty Ltd., Sydney.

JAKOBI, Á. (2017): Big spatial data, avagy új lehetőségek a területi döntés-előkészítés támogatásában Új Magyar Köqigazgatás 10 (3): 27-33.

JENEY, L.-VARGA, Á. (2016): A kreativitás térszerkezetének változása Magyarországon az ezredforduló után. In: TózSA, I. (ed.): Humán tér-kép. A bumán és fejlesżtéspolitikai tényezoók földrajza Magyarországon pp. 15-56., BCE - PAGEO Alapítvány, Budapest.

JÜPTNER, P.-KRUNTORÁdovÁ, I. (2015): Local government in the Cqeech Republic Les éditions IMODEV, Paris.

KADÉT, E.-VARRÓ, G. (2010): A roma lakosság hozzáférése az uniós fejlesztési forrásokhoz SzabolcsSzatmár-Bereg és Borsod-Abaúj-Zemplén megyében TASZ, Budapest.

KANÓ, I.-KAZEMI-SÁNTA, É.-LENGYEL, I. (2017): Territorial distribution of highly educated individuals in Hungary after 1990 Regional Statistics 7 (2): 171-189. https://doi.org/10.15196/RS070209

KLIMOVSkÝ, D.-Pinterič, U.-ŠAPARniEnÉ, M. (2016): Human Limitations to Introduction of Smart Cities: Comparative Analysis from Two CEE Cities Transylvanian Review of Administrative Sciences 47.E/2016: 80-96.

LUKÁCS, GY. (2017): Mélyszegény közösségeket támogató szektor Magyarországon BADUR, Budapest.

Regional Statistics, Vol. 10. No. 2. 2020: 206-227; DOI: 10.15196/RS100212 
MATĚJovÁ, L.-NemEC, J.-KŘÁPEK, M.-KLIMOVSKÝ, D. (2017): Economies of Scale on the Municipal Level: Fact or Fiction in the Czech Republic? NISPAcee Journal of Public Administration and Policy 10 (1): 39-59. https://doi.org/10.1515/ nispa-2017-0002

MÁTYÁS, SZ.-SALlaI, J.-TiHANYI, M.-VÁRI, V. (2019): A rendőri elérhetőség és a bűnözés közötti összefüggések térbeli elemzése Területi Statisztika 59 (2): 152-163. https://doi.org/10.15196/TS590202

MÉSZÁros, R.-JAKOBI, Á. (2013): A virtuális tér gazdasága. In: JENEY, L.-KulCSÁR, D.TÓZSA, I.: Gazdaságöldrajzi tanulmányok közgazdászoknak pp. 193-214., BCENGM, Budapest.

Mickoleit, A. (2014): Social Media Use by Governments: A Policy Primer to Discuss Trends, Identify Policy Opportunities and Guide Decision Makers OECD Working Papers on Public Governance, No. 26, OECD Publishing, Paris. http://dx.doi.org/10.1787/5jxrcmghmk0s-en (downloaded: 2017. 12.04.)

NeMEC, J.-Merickova, B.-OCHRANA, F. (2008): Introducing benchmarking in the Czech Republic and Slovakia Public Management Review 10 (5): 673-684. https://doi.org/10.1080/14719030802264424

NemeC, J.-MatĚjová, L.-SoukopovÁ, J. (2016): Small Is Beautiful. The Pros and Cons of Territorial Fragmentation Regarding the Example of the Czech Republic. In: SAdioglu, U.-Dede, K. (eds.): Comparative Studies and Regionally - Focused Cases Examining Local Governments pp. 113-133., $1^{\text {st }}$ Edition, Chapter 6, IGI Global, Hershey PA, USA.

Pinterič, U. (2010): Development of E-Government Services for Citizens in Slovenia Theory and Practice Journal Eastern European Economics 48 (3): 88-98. https://doi.org/10.2753/EEE0012-8775480305

PINTERIČ, U. (2020): The Use of ICT by Ignorance of the Citizens Faculty of Organisation Studies in Novo Mesto, Slovenia.

PÉnZes, J.-TÁTRAI, P.-PÁszTOR, I. Z. (2018): A roma népesség területi megoszlásának változása Magyarországon Területi Statisztika 58 (1): 3-26. https://doi.org/10.15196/TS580101

SzARVÁK, T. (2004): A digitális szakadék, mint új periféria-képző jelenség Tér és Társadalom 18 (3): 57-75. https://doi.org/10.17649/TET.18.3.958.

TAgAi, G.-BERnARD, J.-ŠIMON, M.-KoÓs, B. (2018): Two faces of peripherality: labour markets, poverty, and population dynamics in Hungary and Czechia Regional Statistics 8 (2): 19-45. https://doi.org/10.15196/RS080204

WiRTZ, B. W.-SCHILKE, O.-UlLRICH, S. (2010): Strategic development of business models: implications of the Web 2.0 for creating value on the internet Long Range Planning 43 (2-3): 272-290. https:/ / doi.org/10.1016/j.lrp.2010.01.005

Regional Statistics, Vol. 10. No. 2. 2020: 206-227; DOI: 10.15196/RS100212 